\title{
City Architecture as the Production of Urban Culture: Semiotics Review for Cultural Studies
}

\author{
Daniel Susilo; Mega Primatama \\ Universitas dr. Soetomo, Indonesia; University College London, United Kingdom \\ Corresponding Author: daniel.susilo@unitomo.ac.id
}

\begin{abstract}
This article aims to describe the correlation between city's architecture as urban culture and cultural studies, specifically in semiotics. This article starts with Chris Barker's statement about city and urban as text in his phenomenal book, Cultural Studies, Theory and Practice. The city as a complex subject has been transformed into the representation of urban culture. In the post-modernism view, urban culture as cultural space and cultural studies' sites have significantly pointed to became communications discourse and also part of the identity of Semiology. This article uses semiotics of Saussure for the research methods. Surabaya and Jakarta have been chosen for the objects of this article. The result of this article is describing the significant view of architecture science helps the semiotics in cultural studies. In another way, city's architecture becomes the strong identity of urban culture in Jakarta and Surabaya. Architecture approaches the cultural studies to view urban culture, especially in symbol and identity in the post-modernism era.
\end{abstract}

Keywords: city's architecture; urban culture; semiotics; cultural studies

\section{INTRODUCTION}

Giddens (1993) in Lubis (2014:4) stated the society is like a building who need reconstruction every day and human-created their reconstruction. Based on Giddens's stated, our society is like our city building. Their social life and norms can represent how their building reconstruct. The city and urban culture are simply like Latin's concept, Recto verso. They are each binding, and also filling each other.

The idea of relations between city and urban culture have depth research in outside Indonesia. Names such as Deborah Stevenson, doing the depth research with this concept with Anthropology perspective. In another way, this article will describe the context of city architecture and urban culture in Architecture perspective with a semiotic approach in cultural studies perspective influence.

An urban society is clearly cannot be separated from the form of the city itself. A city grows through the time and the people watched it grow and develop. Through the ages, the modernization, and the urbanization, a city that used to be not that big become so large that has to prop up the need of its growing citizens. As the city develops, so does the people improvements. From the large bond of the agricultural society to a pure and "modernized" urban society. The urban lifestyle itself differs into a large spectrum: by age, salary, job, dependents, et cetera. Every single building in the city could speak its influence on the people of a certain spectrum. Whether the people is rich, poor, uneducated, educated, et cetera. Everybody has its own place in an urban building.

Beginning the history in the fourth century, in the wake of Kutai Hindu's kingdoms, and become greater at its highest peak: Srivijaya and Majapahit, the two largest kingdoms in this country. The two kingdoms have its own capitals: Palembang in Southern Sumatra and Trowulan in the side of Mojokerto - East Java. Of course, these two cities were thought to be large cities of its time. But more developing urban communities have seen in the island of Java. It all 
starts with a small harbor on the northwestern part of Java. Through the years, waterfront cities became more developed than landlocked one thanks to the trading activities by ships and become Jakarta. Other cities soon followed, especially on the northern coast of Java.

Jakarta as the capital of Indonesia, used to be the areas of a small city and wide areas of settlements. Due to the economic growth and urbanization of the people outskirts the city, Jakarta becomes a metropolitan with the large spectrum of urban life. Another object on this research is Surabaya, the second largest city in Indonesia. First habituated as an exile prison around the 9th century and established in 1293, Surabaya has been a large node of harbor activity, trading and exporting resources to the archipelago and the world. The economic activity then becomes the main rotating dynamo of Surabaya.

Recently, people have seen the growth of middle-class society, a class who has access to the latest lifestyle standards, moved by the power of social media, the western lifestyle on large types of media, and the rise of the "Y Generation", large quantities of building were built to meet the need of their access to urban lifestyle such as western-influenced café, malls, department stores, factory outlets, et cetera.

Buildings were also made to make itself more attractive, either by its façade or the interior to attract those young generations to come and spend time and money there. Of course, these designs, as the point of view of architecture, were seen as something that less important than its function. But in recent years, due to the demands from the middle-class society, the building has shown its contemporary architectural aesthetic on the building, these buildings had identified themselves as the high-class place. In relations with Barker's (353) statement, urban representation portrays itself as creative people. Building architecture in relations with capitalism (Barker 355-356) also has the deep connection with economic interest with urban society.

The researcher using semiotics review from Saussure to analyze the sign and signifier of the City building in Jakarta and Surabaya. Saussure offered a 'dyadic' or two-part model of the sign. He defined a sign as being composed of: a 'signifier' (signifiant) - the form which the sign takes; and the 'signified' (signifié) - the concept it represents. In this research, signifier was the City Architecture and the signified was the urban culture representation.

\section{RESULTS AND DISCUSSION \\ Urban Development in Indonesia: Jakarta as Symbol of Cosmopolitan}

Impact of urbanization is raising various cultural background and ethnicity of the urban people. Jakarta in other way is already becoming a large Metropolitan and high-class communities formed but also has provided space left for the middle-low class to still get updates from the latest lifestyle. Kusno (2000) stated during the post-colonial Old Order of Soekarno and the New Order of Soeharto a drive to promote the formation of an "Indonesian Architecture" has unmistakably taken hold.

The big facelift of Jakarta was started when Jakarta was appointed as the host of the 4th Asian Games in 1962. Large and monumental constructions were erected such as Hotel Indonesia (now Hotel Indonesia-Kempinski), Sarinah Department Store, and Senayan Sports Complex. Those world-class facilities were built altogether with the Istiqlal Mosque, National Monument, and statues all over the city to show the world that there is an emerging power between the two opposing poles of power in the Cold War.

There is also the waves of urbanization that started in the 1950s, when Indonesia's situation was relatively unconducive due to some disintegration movement across the country, mainly in West and Central Java carried by Islamic separatist movement that was terrorizing villagers. The urbanization also supported by the stabilized state of the capital at that time.

Another big development was carried out by Governor Ali Sadikin, who erased the existence of traditional vehicles and improve villages to become more hygiene and healthy. There are also many roads were built and lands were opened to make space for new edifices. Jakarta was transformed from "Giant Kampong" into Metropolitan.

Around the $80 \mathrm{~s}$, business was booming. The large flow of investments and economic stability brings foreign group started to build their company and branch in Indonesia and made the Jakarta as the economic hub of the country. There are also some consequences such as the growing of middle-high class, the development of department stores, business district, et cetera.

Jakarta in recent years saw a little significant development because the city is already growing in the 1980s and not much land was still empty and 
unoccupied. The development itself is starting to take place in Jakarta's satellite cities inside the Megapolitan of Jabodetabek.

\section{Urban Development in Indonesia: Surabaya as Symbol of Growing Metropolitan}

There are similarities and differences between both cities, Jakarta and Surabaya. But what differs them the most is the cultural aspects of Surabaya. Jakarta is already packed with people from the various ethnic background (even the native ethnic feels marginalized recently) so it makes the city more plural than Surabaya.

Surabaya itself, by demography, is dominated by Javanese, followed by Madurese, ChineseIndonesian, and Arab-Indonesian so the Javanese influence is still strong in this city. Although, urban lifestyle is starting to take over bit by bit some life habits that already existed for centuries.

The development in the city was not much seen as Surabaya since the colonial periods are already identified itself as a trading city so the center of traditional economic zones still can be seen today. Surabaya was small and surrounded by two districts that providing plantation, agriculture, and heavy industrial matters: Djabakota and Goenoengkendeng. Both of those districts were slowly erased and integrated into the city and expanding the city border.

In the 1980s, business was growing rapidly, the old business district was replaced by the new one on the southern part, making already-existed housing and villages were transformed into new buildings and towers. The development was continued to spread to the east, supported by good and big roads built by the Dutch colonial government. The elite Dutch housing district also replaced and pushed the new settlements eastward.

The waves of urbanization in Surabaya were started around the 1980s, marked by the development of new public transportation facilities that went southbound and eastbound, made the new housing complexes were built on the south and east of the city first. The city development in the city's western part was a little bit later than the other part because of its hilly land and infertile soil.

The starting of the development marked by the new toll road that connects Surabaya to its neighboring cities, Sidoarjo, Pasuruan, and Gresik. The government, in partnership with private developers, created some new infrastructure projects, such as
Mayjen Sungkono Boulevard and HR Muhammad Boulevard. Both new wide boulevards were integrated with new housings in a project of Darmo Satellite City.

But, compared with Jakarta, Surabaya is still developing and paving its way to a new phase of metropolitan, due to the later wave of urbanization, which occurred in the $1980 \mathrm{~s}$. There is still a lot of empty land in the cities but development in neighboring cities also gives the impacts. New high rise buildings were erected and new elite housings were built and started to change its society to be a fully urbanized community with the middle-high class society as its leader.

To observe about the urban lifestyle change and divisions, this paper will take two examples of the vital node on an urban life: airport and department store. Airport was chosen because it represents an identity of a place, city, or even, a nation. Department Store was the other reason why this paper is important because this building is also watching the city move and develop itself. As the objects of this research, Jakarta and Surabaya will be explained on its airport and department store examples.

\section{Crossing between Architecture and Culture Production in Semiotics Perspective (JAKARTA)}

Jakarta is the most popular city in Indonesia, with its status as the national capital. It is also has seen the change in the society for centuries. The architectural object for this research is Soekarno-Hatta International Airport and Mal Taman Anggrek.

Soekarno-Hatta International Airport (SHIA) is the primary airport serving the Greater Jakarta area on the island of Java, Indonesia. Named after the first president and vice-president of Indonesia, Soekarno and Mohammad Hatta, the airport is located in Benda, Tangerang, approximately $20 \mathrm{~km}$ northwest of central Jakarta.

Aside from the problems of social imbalance and human rights problem, business in Indonesia in the 1970s to 1980s was booming and the nation was also observed the highest point of the economic achievement since the nation's independence. It was supported by a stable government, high economic growth, and continuous, gradual, and integrated development plan by the government. It was no surprise that at that time there was a large amount of foreign investment in this country which became a speeding economic dynamo. 
The impact of the economy and the developing world's aircraft industry made the air traffic mobility saw the large annual increases, larger from the world's average at that time. The two already-existed airports in Jakarta; Kemayoran Airport for the domestic flight, and Halim Perdanakusumah International Airport for the international flight, started to reach its maximum capacity and could not hold anymore beyond its limits. The government started the plan for the new airport in 1975 with help from Aeroport de Paris and architect Paul Andreu, who's also designed Paris Charles de Gaulle Airport. The construction phase was started in 1980.

Figure 1. Soekarno Hatta International Airport signage board (Source: Wikipedia)

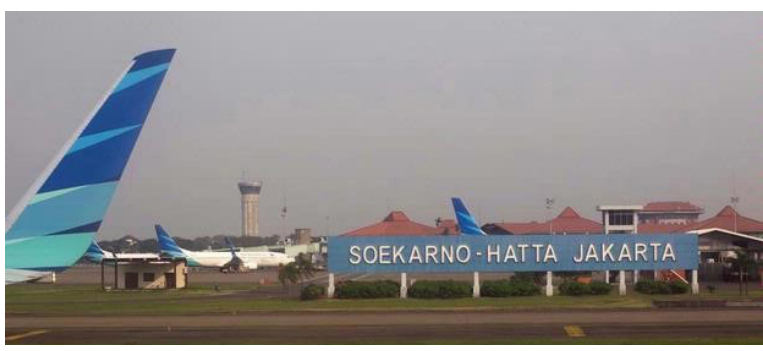

Based on the architectural views, there are some changing in airport's design through the phases, due to the advancing technology and recent architectural style. There are two distinct terminals in SHIA that resemble the changing of time and taste in design: Terminal $1 \& 2$ and Terminal 3 \& 3 Ultimate.

\section{Terminal 1 and Terminal 2: The Resemblance of Local Influence}

Terminal 1 was finished on 1985 and the second terminal followed 7 years later. Terminal 1 is recently serving most of the domestic flight, while Terminal 2 is serving all international flight and domestic flight served by Garuda Indonesia and Merpati Nusantara Airlines (but in the near future will be replaced by Terminal 3U).

These terminals were built as the gateway of Indonesia so it reflects the culture, tradition, and aspirations of the people. It was built as a symbol of a nation and its people so it should be built as a masterpiece, rather than a conventional-designed, characterless monument. The design was inspired by the architect's experience when visiting Jakarta. It was influenced by the scattered houses in villages surrounded by acres of paddy fields.
Figure 2. Aerial View of Terminal 1 and 2 (Source: Wikipedia)

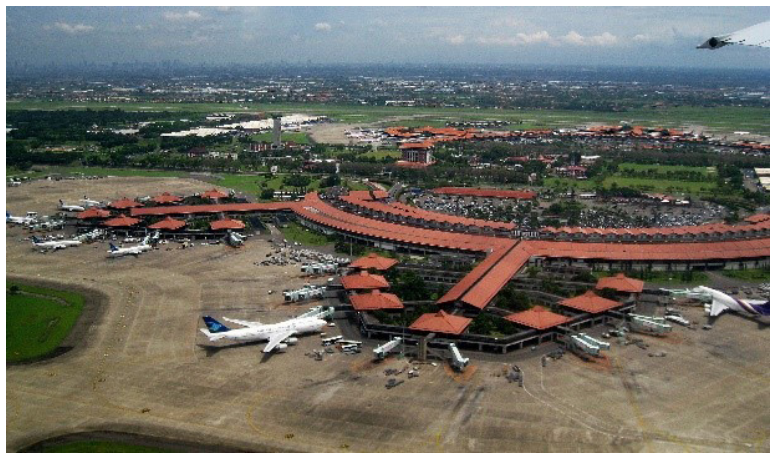

Figure 3. Gardens inside the airport, surrounding boarding lounges. (Source: aeroinside.com)

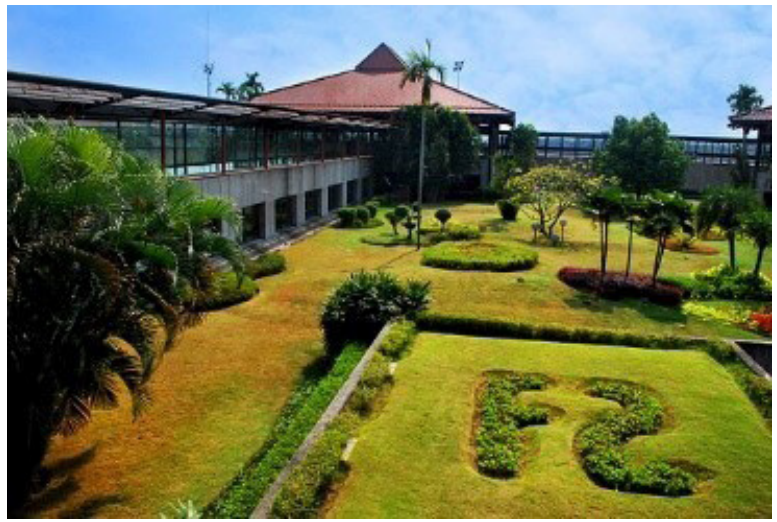

Figure 4. One of the boarding lounge. (Source: Wikipedia)

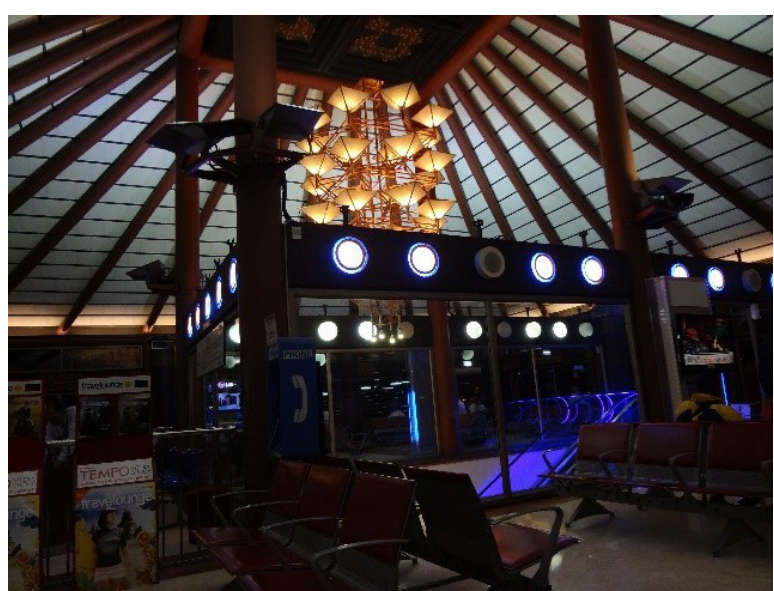


Figure 5. Connecting area, from check-in to boarding lounge (Self documentation)

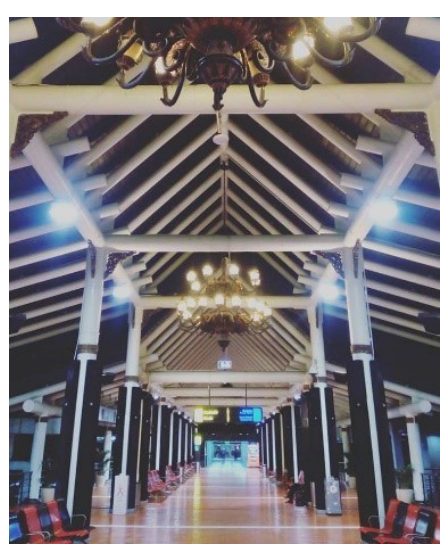

The structure was inspired by West Javanese traditional house. The connecting area from checkin to boarding lounge in Terminal 1 uses the Julang Ngapak style house. Meanwhile, the Jolopong style was used on the landside structure.

The boarding lounge was built in Central Javanese traditional house style (Joglo), clustered in "houses", connected by a bridge and surrounded by gardens that reflect the daily life of Indonesian villagers. There are also some small gardens in various place to make the space for ventilation and the ambience of Indonesia.

Figure 6. Terminal 2 check-in area with Dayak style reliefs. (Source: panoramio.com)

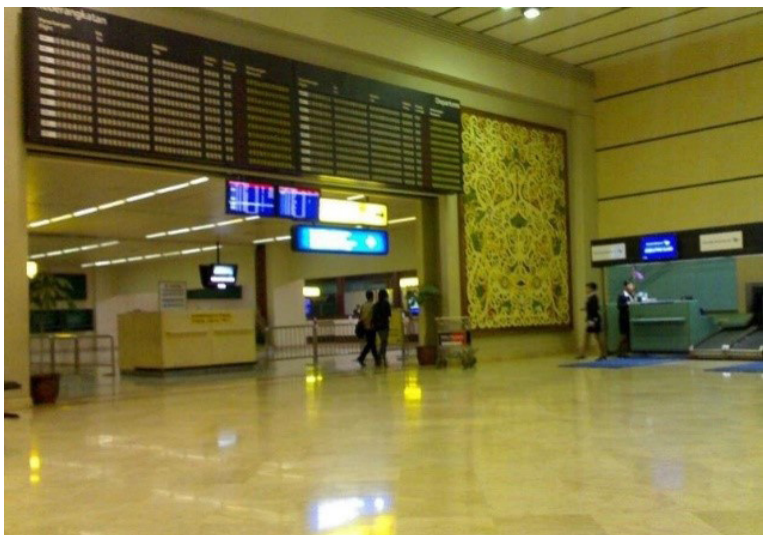

There are also details on Picture 6 to 9 that resembles the airport as the gateway of Indonesia. By showing the Indonesian traditional art that differs from the world, so the passengers that will leave or come to the country is feeling the Indonesian influence, feeling differences from their original homeland.
Figure 7. Lampung ship details on arrival area, Terminal 2. (Source: Skyscrapercity.com)

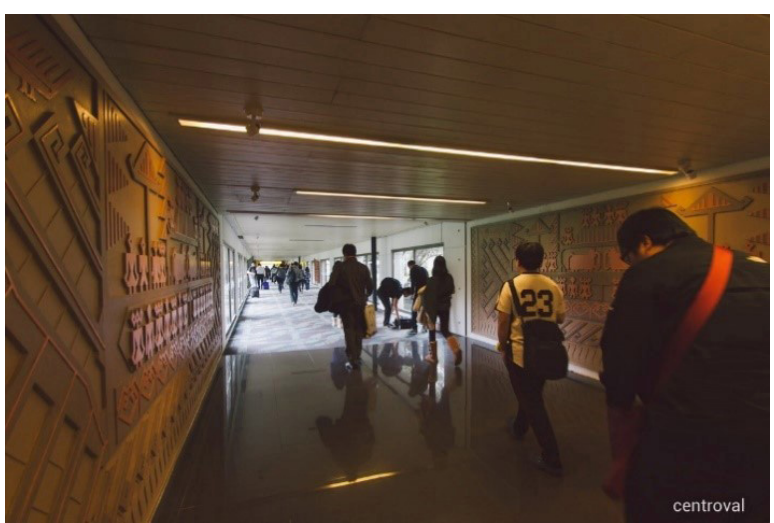

Figure 8. Balinese reliefs on the gate to the Connecting Area, Terminal 1. (Self documentation)

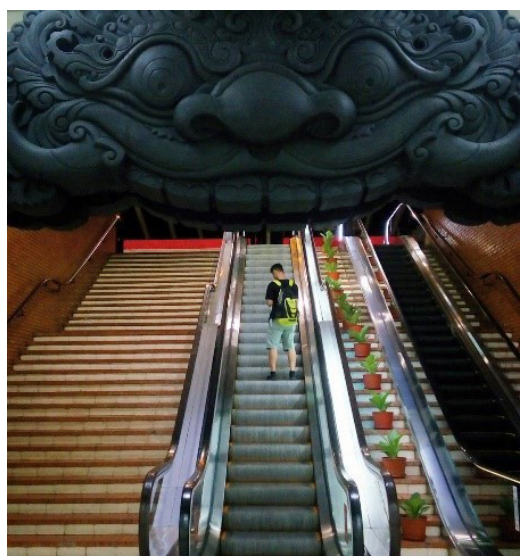

Figure 9. Departure lounge, Terminal 1 with detailed finishing on column (before repainted in 2015) and chandelier as accent and lighting aspect. Note the floor was also the heritage of Indonesian handicraft with local marble and red bricks. (Source: Liburkeluarga.com)

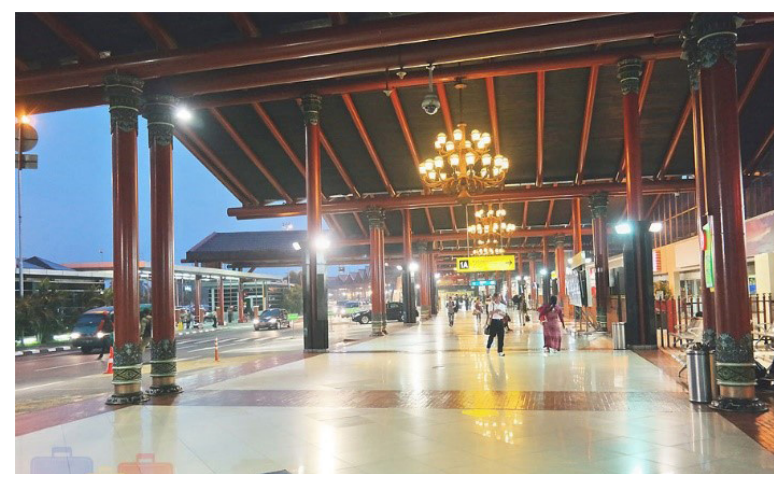




\section{Terminal 3 \& 3 Ultimate: The Future with the Taste of Indonesia}

Terminal 3 of SHIA divided into two phases: Terminal 3 (T3) (Phase I, opened in 2009) and Terminal 3 Ultimate (T3U) (Phase II, under construction, expected to open in June 2016, but delayed). From the aspect of size, T3 is much smaller and handles fewer passengers than T3U. T3 is now handling 4 million passengers annually, serving for all Air Asia flights and Lion Air bound for Bali. T3U, together with T3 is expected to handle 25 million passengers per year and will be serving all Garuda Indonesia and International flights.

Figure 10. Bird's eye view of Terminal 3 and Terminal 3 Ultimate, Soekarno-Hatta International Airport. (Source: ArchDaily)

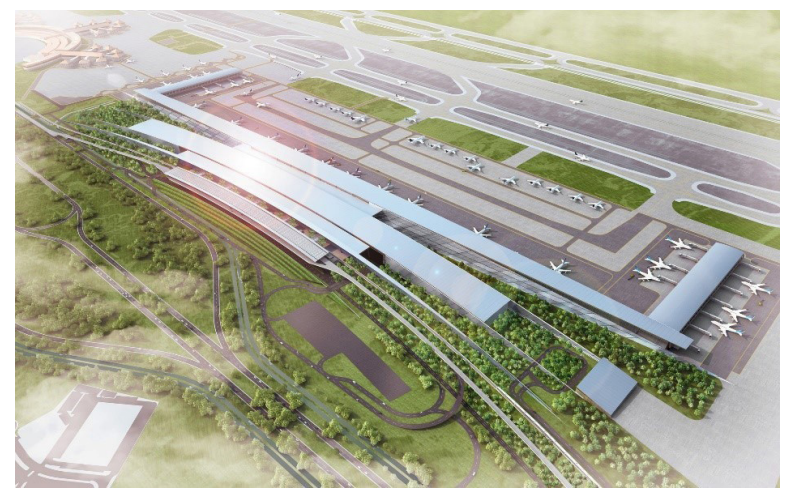

The background of the design itself began on the early construction of the airport itself. The planned shape was to duplicate the previous terminals, still bringing the form and design that heavily influenced by Indonesia's traditional aspects.

Figure 11. Early site plan for the new Jakarta Airport. Top left is Terminal 2, bottom left is Terminal 1 , and the bottom right is the future plan for Terminal 3 .

(Source: 1995 Technical Review, Jakarta Airport Terminal II, The Aga Khan Award for Architecture)

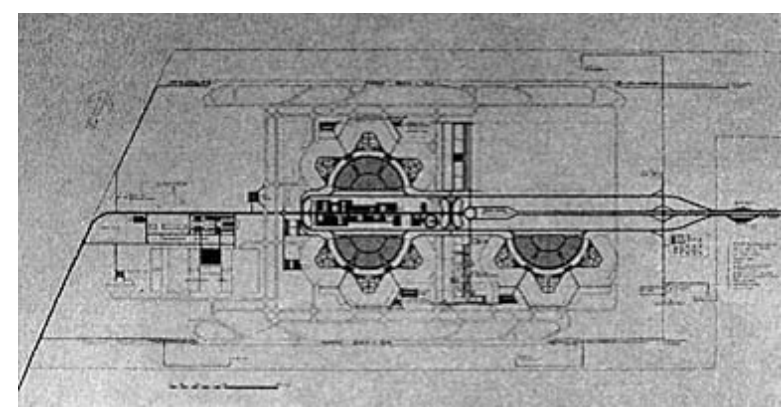

Figure 12. Grand Design for SHIA. The shape and location plan for Terminal 3 is already altered from the 1995 master plan. (Source: SHIA Grand Design video, screenshot and re-uploaded on skyscrapercity. com)

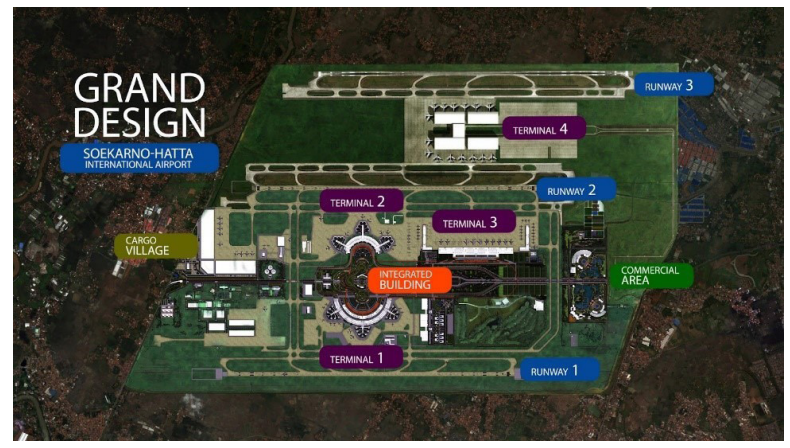

From this point, the new achievement of technology brings a new horizon for world's architecture style. The concrete post-and-beam structure is still used but there are significant changes in the building's envelope and roofing. The shape of $\mathrm{T} 3+\mathrm{T} 3 \mathrm{U}$ itself becomes radically changed to be more simple and easy to build.

Terminal 3 Phase I was built with the ecofriendly modern design. This reflects on the final form: a low-profile building without minuscule details, like in Terminal 1 and 2. The construction method for this new terminal is still using post and beam for certain structure, but the new method that radically shaped of the new airport is the using of the arch steel frame, made it different with Terminal 1 and 2 that used Java's traditional house philosophy. This new roofing structure then makes the room more spacious, because the supporting beam only located on the side of the building.

Figure 13. Terminal 3 Phase I airside lounge. (Source: travelliterature.com)

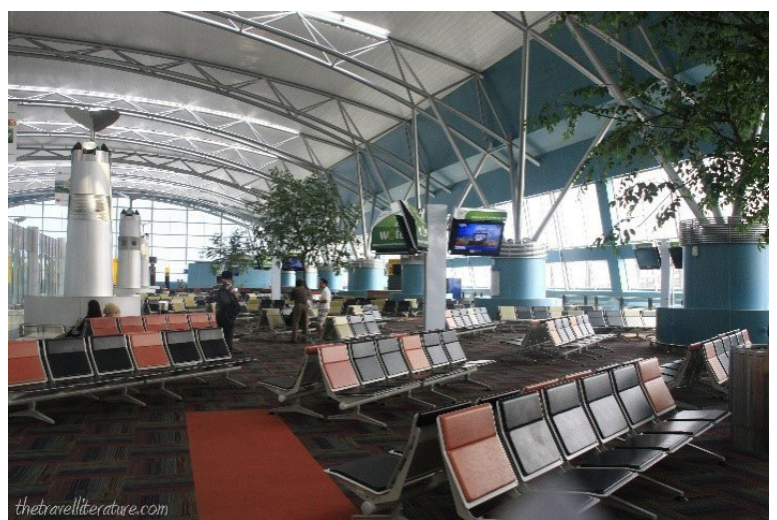


Figure 14. Bird eye view of Terminal 3 Phase I. Note the semi arch roof structure of the airside building formed by the steel frame. (Source: tritunggalprima. com)

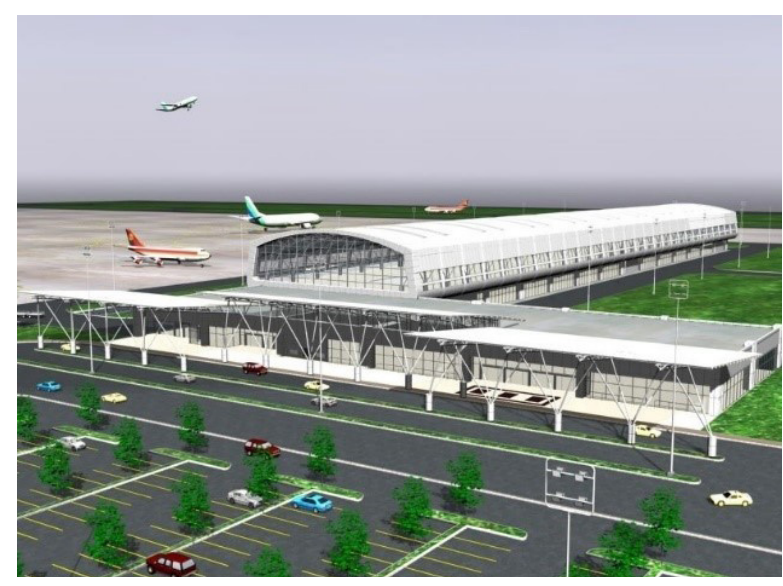

Another significant change from previously existed terminals is the use of glass as building's side wall. Usage of glass also made the efficiency on electricity spending by day because of natural sunlight that goes straight into the building so the usage of lamps can be reduced. There is also change saw on the colour palette usage, which is dominant turquoise for the walls and yellow for the signage, marking the modern era of simple and functional building.

There are no significant traditional details on Terminal 3 Phase I, except the small Mega Mendung batik pattern on signage, which has been introduced in Terminal 3 first, then spread to glass doors across SHIA.
Terminal 3 Ultimate (T3U) is the final phase of the latest new terminal development in SHIA. The ground-breaking for this final phase was started in August 2012 and expected to open in 2016. T3U now becomes the grand answer of overcapacity that happens in recent years. After expanding the capacity of Terminal 1 and taxiway maintenance.

Same with its predecessor, T3U uses ecofriendly modern design. Also, it uses state-of-theart style and light materials. But due to its purpose as the main hub for Garuda Indonesia and all of the international flights, there are a lot of differences were made from the Terminal 3 Phase I. The main building was shaped in simple, a little bit arched, long stripes for about 400 meters on landside and 1.3 kilometers on the airside. It was built to accommodate a lot of planes that coming on SHIA.

From the images 16, it is conclusive that $\mathrm{T} 3 \mathrm{U}$ is divided into two main floors: departing flights on the upper floor and the arriving flights go to the ground floor. The Departure floor is not covering all of the ground floors so they make a tall space above the arrival hall on the ground, to make the arrival space huge and bright, giving a warm welcoming feeling. The latest example on this arrival hall in Indonesia is on Ngurah Rai International Airport, Bali.

The Departure floor was connected to the access road by a bridge to bring them directly to the check-in counter without any access limitation. According to the rendered image, this flow is kind of new in Indonesia, regarding the limited access (passengers only) on check-in counter. Meanwhile, the arriving activities will be done on the ground floor

Figure 15. Left - Mega Mendung pattern (Source: kaskus.com); Centre - First trial of "retouched" pattern to signage on Terminal 3 Phase I. (Source: airport.id); Right - "Retouched" Mega Mendung pattern, applied on

Terminal 2 security gates. (Source: skyscrapercity.com)

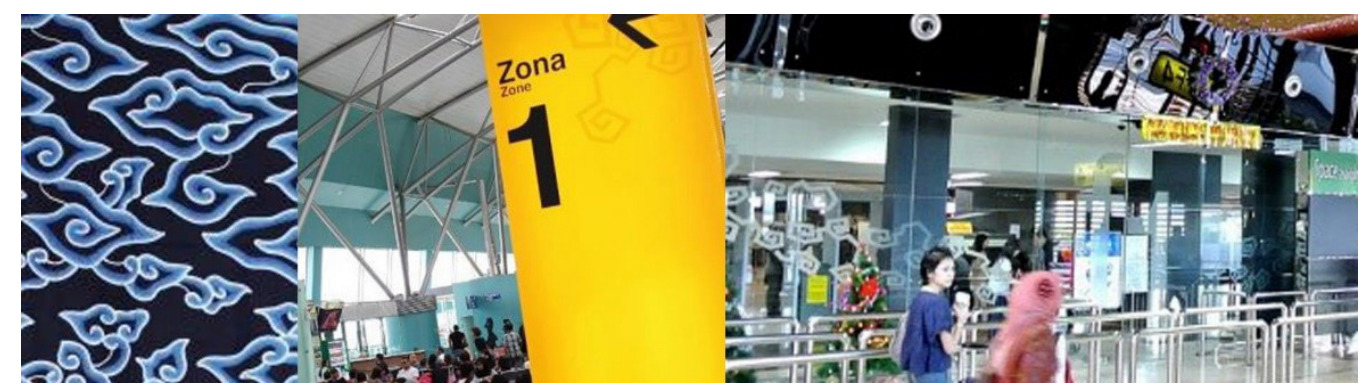


with the last sequence of the journey is at the tall and spacious arrival hall.

Figure 16. Rendered images of Terminal 3 Ultimate, project by Woodhead Architects ( from top left, clockwise): Departure lounge and check-in area, Airside shops arcade, Bridge from Drop-off area to Departure lounge and front garden with inter terminal automatic people mover, Baggage claim area.

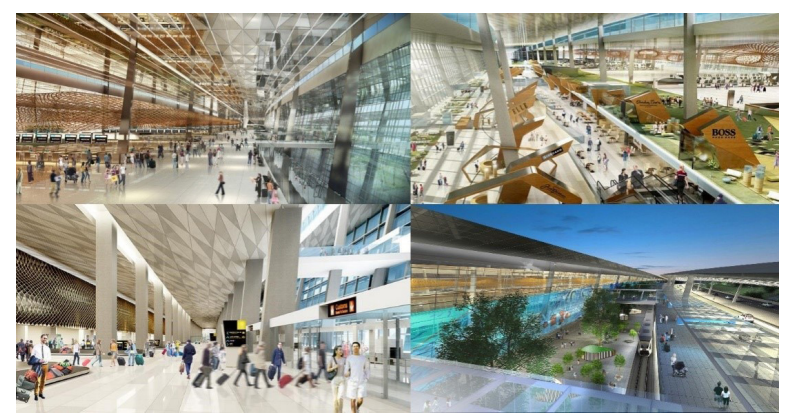

The color palette used is the mix of future and the past. The future is symbolized with white, pale grey, and silver. The material was finished with those color palette to show the clarity and transparency of new airport, bringing them towards the future. There is also the color of "past" that brings the natural sense, symbolized with wood brown as the remembrance of Indonesian who uses a lot of nature aspects in their daily activities.

Figure 17. Arrival hall, Ngurah Rai International Airport. It has same looks with the SHIA's design on arrival hall. (Source: almostlanding-bali.com)

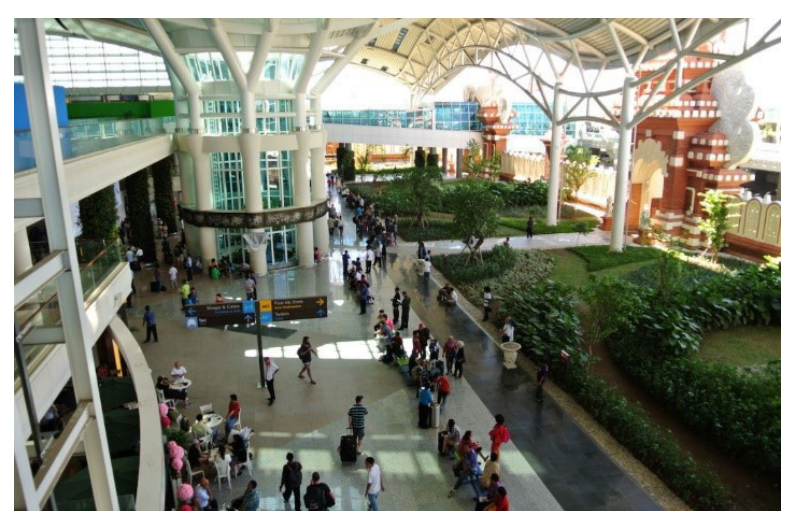

The roofing structure for the upper floor is tilted flat roof that sustained by tilted concrete post and steel frames and then enveloped by aluminum cladding. Details were not much seen but it saw some advancement by adding the wood material on wall decorations and shop's booths. The similarity with Terminal Phase I is the transparent side wall.

Figure 18. Terminal 3 Ultimate under construction. (Source: left - kompas.com; centre - Wikipedia; right - thepresidentpostindonesia.com

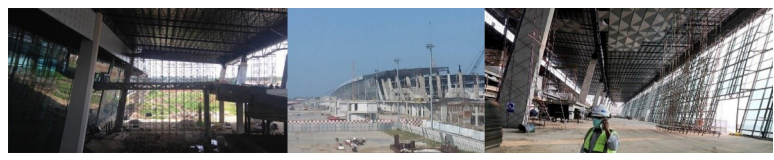

In discussing SHIA Terminal 3, we can't separate from the ambition of the ruling regime. Regardless of whether the interior details affect the financing of the development itself. However, we see how the media responds to the expansion of SHIA Terminal 3 as the nation's pride and representation of the modern Indonesian society.

\section{Department Stores in Jakarta}

One of the most growing aspects of an urban style is the presence of "public area". These public areas in Jakarta usually come in a lot of shapes. The most common reason for the presence of the public area is the economy, their needs for trading and having the business.

The simplest one is the traditional market that grows without any planned development. Went through the development, the traditional market then improved and became planned and not only open on certain days, but 24 hours a day and 7 days a week. The growing of middle-high class in Indonesia also creates a new demand on modern market that comes in good architecture, first-class facilities and first class service too.

In Jakarta, it was implemented by the Soekarno regime to make Indonesia witnessed by the world as a new emerging power. The first modern market (later called as "mall" of "department store") is Sarinah Department Store. Located in newly opened land in Central Jakarta, this department store offers first-class experiences, filled with luxury shops and tenants at that time.

Time goes on, and the Sarinah itself became one of the nodes of Central Jakarta development. And then came a lot of investment and making the Central Jakarta as the economic heart of the city. There is a lots history in the making in this department store. On the beginning of new millennium, Sarinah is the most famous place for hangout, with Indonesian first McDonald's restaurant, Hard Rock Café, and a lot 
of youth radio station were headquartered in that building.

Figure 19. Sarinah Department Store in 1980s (the silver skyscraper on the front), still surrounded by villages that soon to be replaced by new modern buildings and towers. (Source: kaskus.com)

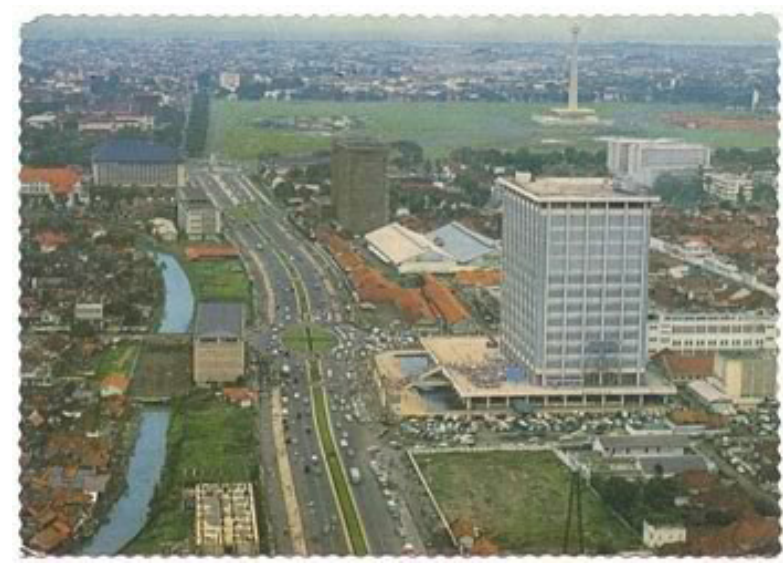

Mall Taman Anggrek is the most high-end department store in Indonesia. The shopping mall was one of the largest in Southeast Asia when opened in 1996. This mall was built by an infamous conglomerate from Kebumen to respond to the needs of urban society in Jakarta that already expanded. Its largest tenants are department stores, cinemas, luxury shops, and gym.

The mall is nestled within eight residential towers and houses more than 500 specialized stores, spread within seven floors. The mall has a gross leasable area of $110,000 \mathrm{~m} 2(1,200,000 \mathrm{sq}$. ft.) and a total building area of $360,000 \mathrm{~m} 2(3,900,000 \mathrm{sq} . \mathrm{ft}$.).

Figure 20. Mall Taman Anggrek at night. (Source: pinterest.com)

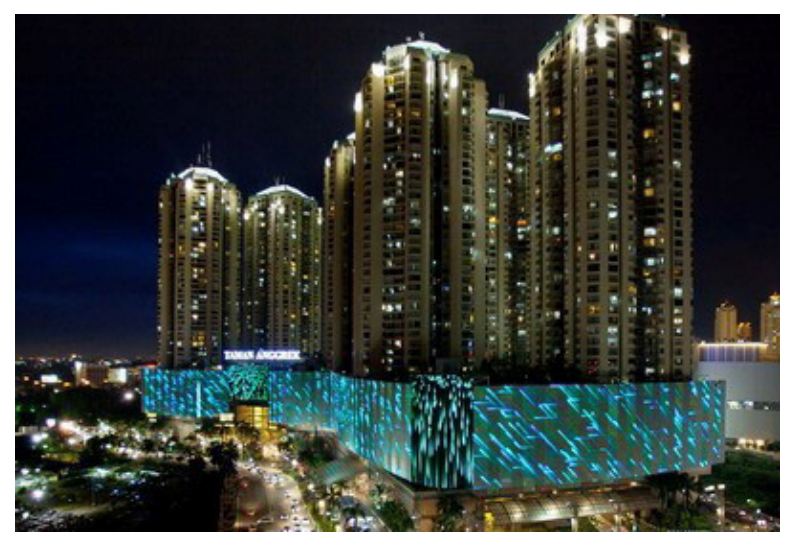

Throughout the complex, there are more than 10 exhibition areas, including a 1000-squaremeter center atrium which hosts major events and exhibitions. The mall also boasts Southeast Asia's first indoor ice rink. Taman Anggrek also hosts the world's largest LED display recorded by Guinness World Record.

By design, this mall is becoming a one-stop living experience when you can fulfil three aspects: work, live, and recreation. This mall already covered it so it makes living here becomes a symbol of urban culture. The architecture style of this building is perhaps not that great if it compared with recent growing malls, but the interior settings, a lot of infamous events that already held here, and the big name of "Mall Taman Anggrek" already made a lot of people want to visit this building, even just for a walk.

This mall is also taking the advantage of its location. On the western part of Jakarta, pretty close with the beating central part of the city, and located beside the airport toll road makes this mall becomes noticeable if a person was driving on the toll road and rethinking for temporary stopped there before continuing the journey to the airport.

Figure 21. Mall Taman Anggrek's interior. (Source: jakarta.panduanwisata.id)

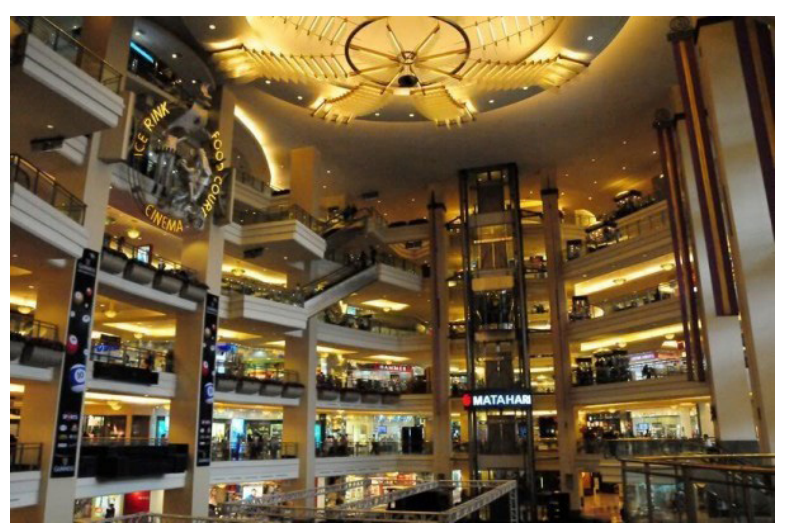

The design and construction type reflects the architectural style of the late 1990s with some conventional techniques. But with the good interior designing, this mall becomes a masterpiece superstore. The palette of yellow and gold and interior style in the 1990s and the large and tall atrium adding the elegant, luxurious, and exclusive ambience. 


\section{Crossing between Architecture and Culture Production in Semiotics Perspective (SURABAYA)}

Surabaya is the second largest city in Indonesia, with its status as the gateway of Eastern Indonesia. It is also seen the change in the society through the centuries. Surabaya expanding from the port hub to eastern Indonesia became the largest City in Eastern Indonesia (Vickers 60). The position of Surabaya became important after major of industrial manufacture, especially sugar, have the strong basis in east Java. Vickers (61) reported base Dutch Colonial estimation, Surabaya has the population of around 150.000 people, making Surabaya bigger than Batavia (now Jakarta) who only have 130.000 population. The architectural object for this research is Juanda International Airport and Tunjungan Plaza.

Juanda International Airport is an international airport located on the regency of Sidoarjo, East Java, approximately 12 kilometers from the city center of Surabaya, the capital of East Java province. This airport serves the Greater Surabaya Area, which is called Gerbangkertosusila. The airport's name is taken after Djuanda Kartawidjaja, the last prime minister of Indonesia, who had suggested the development of this airport.

The background of this airport development was the increasing capacity of air movement in the city of Surabaya, as the city growing and expanding. There was two existed, Dutch-colonial-built airports in Surabaya, the Morokrembangan Airbase (Vliegkamp Morokrembangan) and Darmo Airfield (Vliegveld Darmo) which were built around 1920s.

After the independence, the Morokrembangan Airbase became both hubs for military and civil flights. The increasing of houses around the airport then became the problem for Morokrembangan Airbase. It was also countered with the runway problem that couldn't support the wide-body aircraft. And also due to its location near the busy port that under expansion plan, there was a pressure on developing a new airport that located in quieter place.

Darmo Airfield was dominantly serving for military purposes but once served some civil flights too, but those records were only traceable in Dutch colonial era. The fate of Darmo Airfield after the independence is difficult to search, due to the limited access because the recent location is now fully controlled by the Indonesian Army.

Figure 22. Juanda International Airport signage, Terminal 1. (Source: adiart.us)

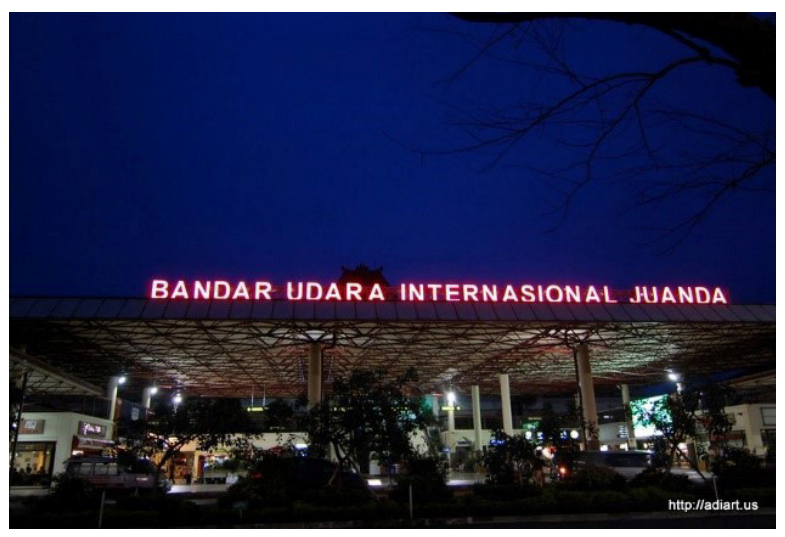

There were studies carried out for the new airport serving Surabaya area, and the land in the district of Sedati in Sidoarjo was chosen to be the new airport took place. The construction phase was started in 1959. In August 1964, the construction was completed and officially inaugurated by Indonesia's first president, Soekarno.

Figure 23. Left - Old terminal, abandoned after Terminal 1 opening, demolished for Terminal 2. (Source: eastjava.com); Centre: Terminal 1, inaugurated in 2006. (Source: Wikipedia); Right: Terminal 2, built on the site of Old Terminal, opened in 2014 (Source: angkasapura1.co.id)

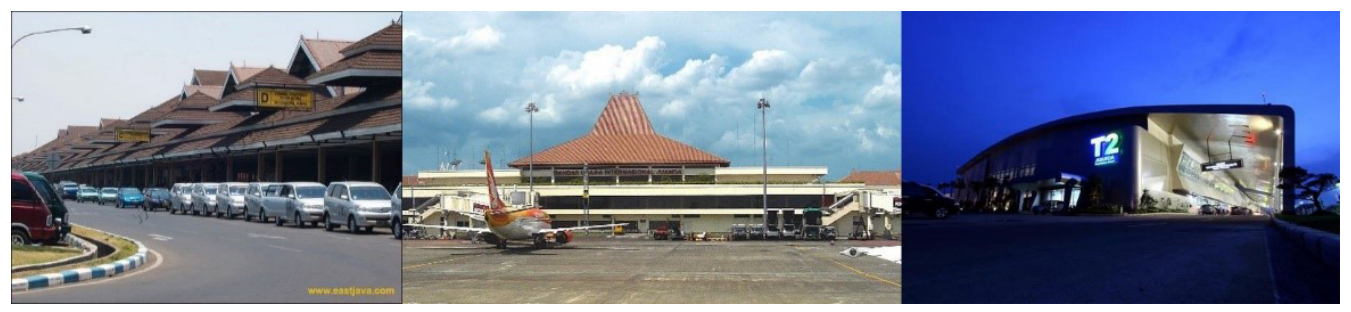


The purposes for the new airport is to serve military and civil services became a joint airport with the Indonesian Navy as the main owner (the official name was then Juanda Naval Airbase). In 1981, flight services were given to Indonesian Government, made the airport more civilian. On 1987, the airport started to serve international flights and then granted the international airport status three years afterwards.

Due to the overcrowding, the new terminal was built on the north side of the runway an opened in late 2006, moving all of the services to the new building named as Terminal 1 . The old terminal was demolished and was built as Terminal 2 in 2011 and officially opened on February 2014.

The difference of architectural approaching aspects on Terminal 1 and Terminal 2 will be the focus on viewing the advancement of technology, the new era of constructing, and growing middle class to travel by aircraft.

\section{Terminal 1: When Conventional Meets Traditional}

Terminal 1 was opened around 2006 to accommodate the airport capacity that previously overwhelmed by the existence of the old terminal. All of the services on the old terminal was moved to Terminal 1 and it was left abandoned. Terminal 1 has two sub terminals: 1A and 1B. Before the opening of Terminal 2, Terminal 1A served all Garuda Indonesia and international flights, meanwhile, Terminal 1B served all domestic flights.

Figure 24. Juanda International Airport Terminal 1. (Source: skyscrapercity.com)

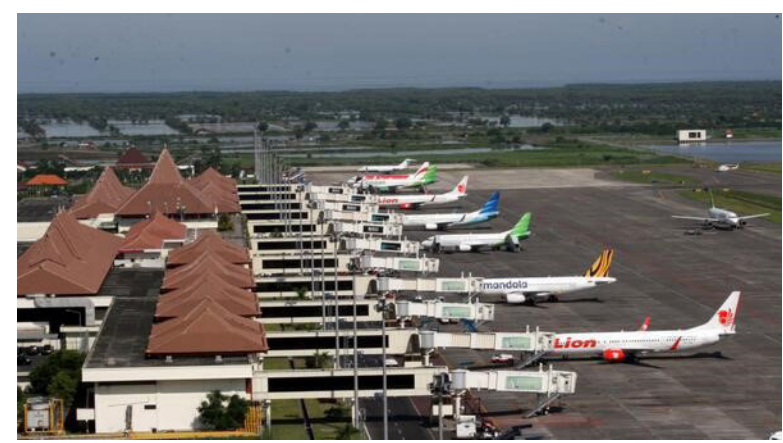

By the condition of the design movement on that year, it was obvious that the design of a building, even for an airport, became more conventional and functional, starting to leave the characteristic of airport's location. But in this edifice, there are some traditional aspects that still preserved. The obvious things are terminal's roofing structure. It uses the concept of enlarged East Java's traditional house, Joglo. The conventional structure is the concrete post-and-beam structure, which at that time was saw as a pretty efficient method to build a structure. The simple structure itself perhaps making an airport more as a building rather than an architecture. So the local elements were then brought here. It makes this terminal as a conventional-structured building and then polished with traditional values.

Figure 25. (From top left, clockwise) Drop zone, using steel frame and flat roofing (Source: jawapos.com); The terminal landside hall, with strong appearance of post-and-beam structure, finished with Javanese relief on ceiling (Source: surabayanews.co.id); Departure lounge with small chandelier and relief on upper walls (Source: YouTube screenshot); The same design is also implemented on Check-in counter, with the bigger chandelier. (Source: kanalsatu.com)

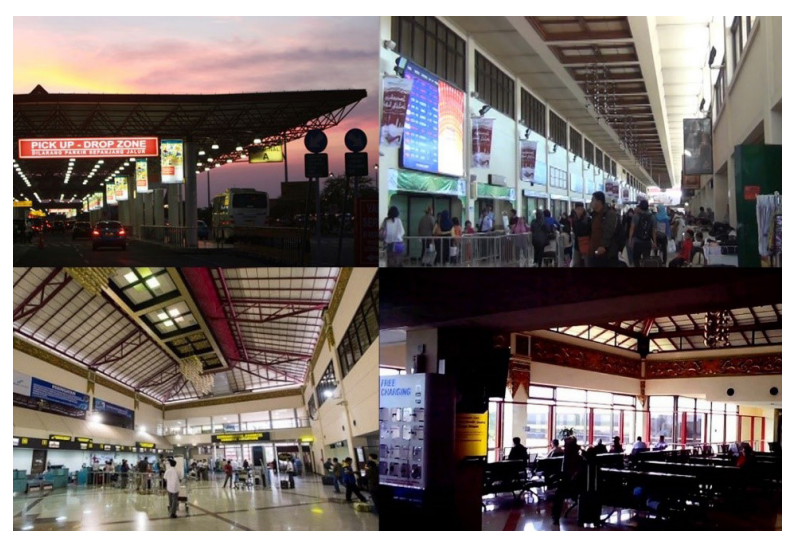

The palette color of this airport symbolizes the East Javanese culture, which is rather more sparkling than Central Javanese, with bright red, dark brown, and gold. These color was placed on the upper wall and also placed on the steel frame so the dominant ceiling is filled with red. The wall itself only using a conventional and maintenance-able pale yellow.

The slightly more complicated part is the details and roofing structure. These two aspects were chosen for bringing the traditional flare. The roof itself is divided into several singular Joglo styles and a large Joglo roof on the center of the airport. The roofing structure also differs on the landside hall and airside. The airside hall is more traditional Joglo style but on the landside hall, it saws more conventional, easy-tobuild, flat roof with all of the main steel frames were painted red. 
Figure 26. Left - Different roofing styles on Terminal 1 (Source: skyscrapercity.com); Right - Terminal 1 Drop-off zone roofing with red steel frames. (Source: e-bandara.blogspot.com)

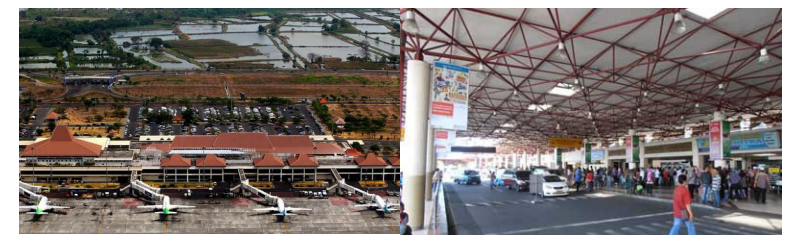

Terminal 2: The Future of Greater Surabaya

Terminal 2 is the second terminal and the latest terminal of Juanda International Airport. Located at the south of the runway, this terminal was used to be the old terminal site, which was then demolished. Terminal 2 was opened on February 14th, 2014. But due to the disaster of Mount Kelud in East Java, which rained the airport with volcanic ashes on its opening day, all of the flights were cancelled and flights from Terminal 2 was boarded several days later. Terminal 2 was the answer of overcapacity that already happened on Terminal 1 several years after its opening and it could handle 6 million passengers per year. But recent data found that both terminals are now in overcapacity and airport's ATC is handling more traffic control than its limit. The plan of Terminal 3 is now going underway and expected to be finished in 2018.

Figure 27. Entrance of Juanda International Airport's Terminal 2. (Source: infopublik.id)

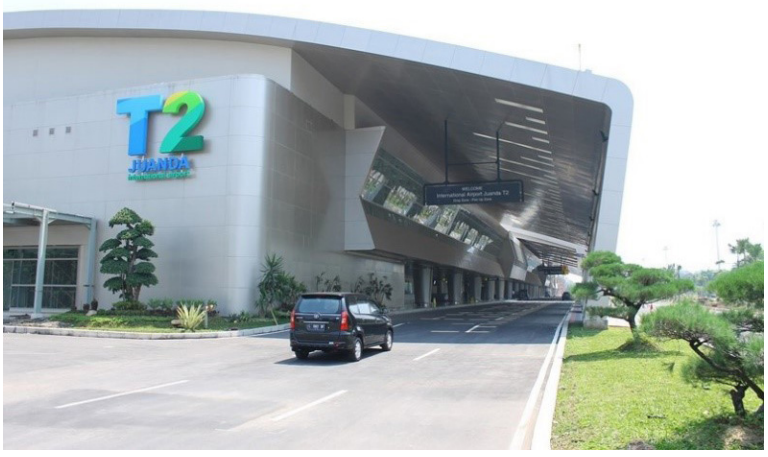

The design of Terminal 2 was claimed as more modern, faster on construction time, but cheaper than Terminal 1, according to Dahlan Iskan, Minister of State-owned Enterprise Affairs at that time. It has similarities with Terminal 3 Phase 1 of SoekarnoHatta International Airport from the roof shape. The material that dominant here is the aluminum cladding for the envelope of wall and posts inside the Terminal. It brings the new atmosphere, more futuristic than Terminal 1 by its design and material.

Figure 28. Check-in counter, viewed from upper floor. (Source: skyscrapercity.com)

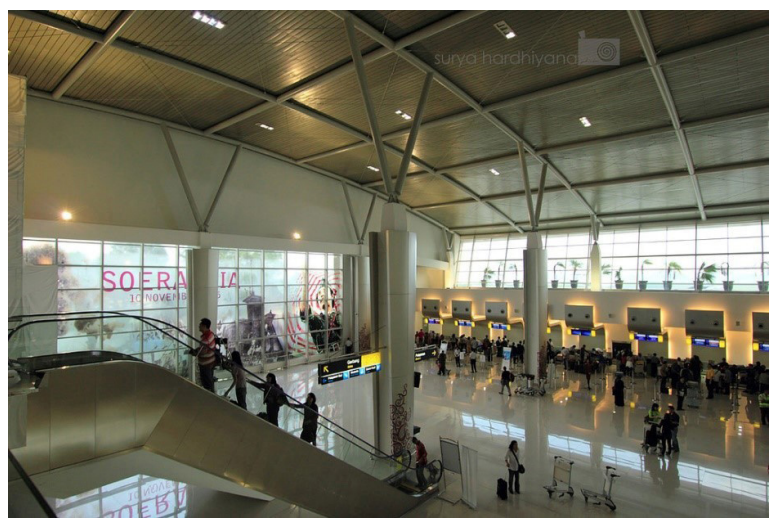

The structure was not entirely using postand-beam. The check-in counter has no second floor and directly attached to the roof structure, making a spacious area for checking in. The departing activities are done on the upper floor, right on Meeting Hall before went to the gates. Meanwhile, the arriving activities are done on the ground floor. The roof structure was different than Terminal 1. There is no visible roof frame either on the drop zone or check-in counter. On check-in area, the roof itself is directly supported by the posts. But in the departure gates on the upper floor, there are some visible steel frames when the airport was still under the construction phase.

Figure 29. Left - Check-in counter. (Source: @ dimasp on skyscrapercity.com); Centre - Meeting Hall Terminal 2 (Source: wikimapia); Right -Roof structure on upper floor, under construction. (Source: Antara News)

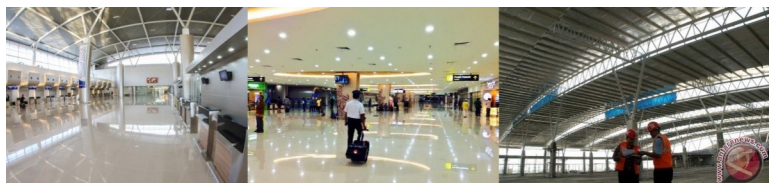

The palette color chosen is somewhat futuristic, with the dominance of silver from the aluminum cladding. It also brushed with wood brown on several surfaces and some yellow for signage and indirect light. The other significant material is the large glass enveloping the airside to make a room looks more 
spacious. The same purpose is also driven by the main palette color.

Figure 30. Floral sticker on every post in Terminal 2. (Source: juanda-airport.com)

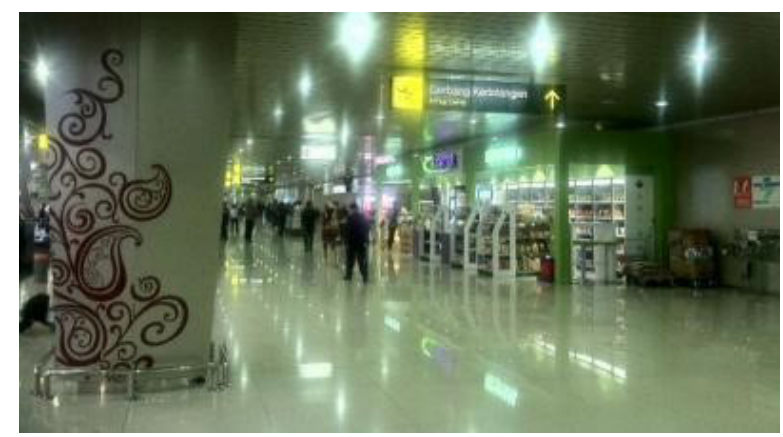

There is almost no detailed ornament, except for the floral sticker on each aluminum-clad post so it does make sense that the budget for this construction is lower than Terminal 1 because of the absence of details and ornament, making this airport looks like any other modern airport in the world with the universal characteristic.

\section{Tunjungan Plaza}

Tunjungan Plaza is the most rapidly growing department store in central Surabaya. Located in the area of the infamous heritage street of Tunjungan, the provincial and municipal administration center, and the city's central business district in Basuki Rahmat Street, this mall becomes the node of new growing urban life in the city. Middle-high class growth in Surabaya happened later than Jakarta. It was happened in the 1980s, in the wake of urbanization waves, growing economy, and increasing people's income.

Figure 31. Tunjungan Plaza Phase 1 and 2. (Source: multicleanindonesia.com)

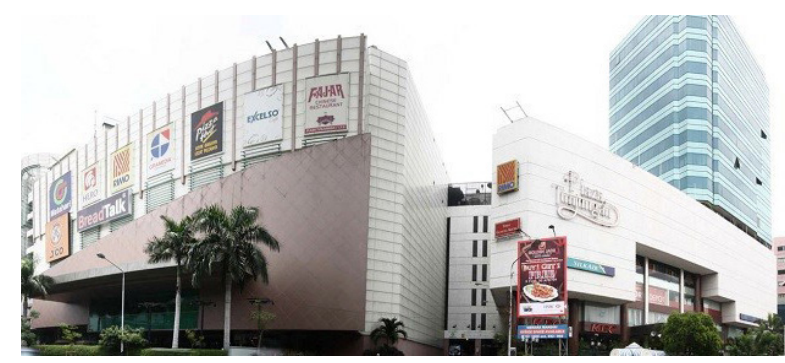

There are several phases on this department store during development. The construction started on 1983 and the first phase of the mall (Tunjungan Plaza
1-TP 1) was opened in 1986 and became the very first department store in Surabaya. The second phase (TP 2) was opened in 1991, located on east side of TP 1. The third phase and the largest phase of that time (TP 3) was finished in 1996. On 2001, the fourth phase (TP 4) was opened and specialized as the premium mall, filled with luxurious and exclusive brands.

On 2012, the development of fifth phase and the apartment (TP 5) was started to build on the site of ex Dutch-styled, categorized as the cultural heritage, Toko Nam store. There was criticism because the remaining façade of Toko Nam was ignored and they keep to build by their own design. The existing façade was slowly tilting due to the land's subside. The developer then made the steel frame to support that façade, till today. The fifth phase development was still going until its opening in September 2015. The other phase was built on the north of TP 4 and was completed with the apartment.

Figure 32. First three phase of Tunjungan Plaza: Left - TP 1 (Source: pradinipus.files.wordpress.com); Centre - TP 2 (Source: eastjava.com); Right - TP 3, built behind TP 1 and TP 2. (Source: tukangbecak. com)

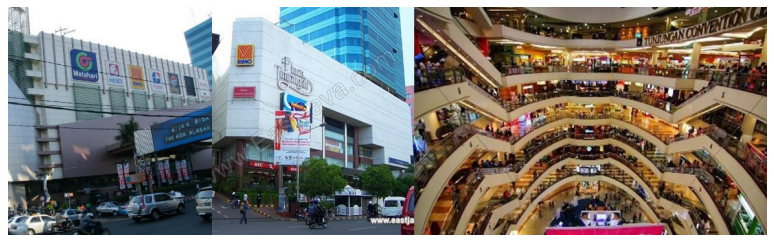

Figure 33. The latest phase of Tunjungan Plaza. Left TP 4, before facade redesign (indonesiawow.com); TP 5 under construction and TP 4 under facade changing (Source: skyscrapercity.com); Right: Final shape of TP 4, TP 5, and towers of residences. (Source: madiunpos.com)

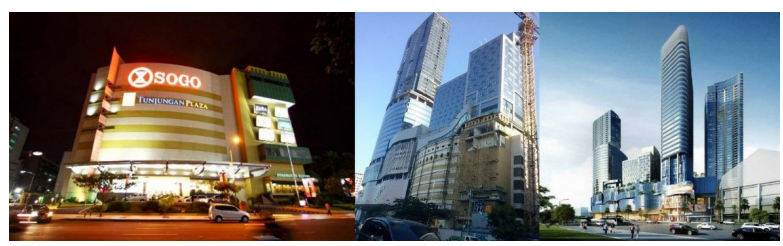

The most obvious aspect that we can see from this mall's development through the age is their envelope style (the only phases that have no façade is TP 3). The late millennium style was applied on TP 1, TP 2, and TP 4. The fifth phase is using aluminum cladding and the envelope than continued to TP 4 and the last phase's apartments. 
Figure 34. Left - TP 4 Interior; Right - TP 5 Interior (Source: foodgrapher.com)

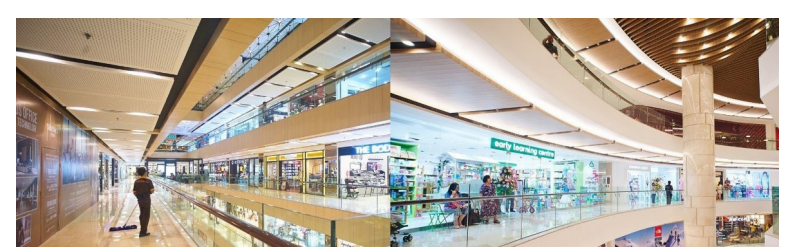

The design on TP 1 and TP 2 are rather more basic and conventional-shaped. But TP 3 is using the latest technology, using the oval atrium and state-ofthe-art ceiling style. TP 4, although built in 2001 with the rectangle atrium, the designers using the lighting engineering well. TP 5 is designed with the latest ceiling and lighting.

It also shows the mall's characteristic as a highend and exclusive superstore. From the mall's design, it was classified as middle-high to high class society, with TP 1, TP 2, TP 3 designed for the middle-high class society and TP 4 and TP 5 for the high class, because the TP 4 and TP 5 will be completed with two apartment towers and a hotels so these made the Tunjungan Plaza as one large one-stop superblock located in the center of the city.

\section{CONCLUSION}

The development of a civilization can be observed by its art, by its building, and by its architecture. As viewed from the architectural sight, Indonesians had seen the last 30-50 years as the age of leap. The age where the traditional values that already ran for centuries have been replaced bit by bit by the new urban way.

The thoughts of traditional way perhaps seen as values from the village, which, for some people, feels unsuitable with their way of life in the city. The city life is obviously different from the village life. You have to move faster, work harder.

This kind of life also comes in form of the high-class, privileged society. The growth of economy growing the middle-high class population up. They are people who would pay more to meet their real needs. They don't mind if they have to pay more expensive for a good, as long as they had a good shopping experience in a well-air-conditioned mall, the goods are in high quality, or even imported. This is the recent change in our society.

By the large populated area, things move so fast. The simplest example in Indonesia is Jakarta, whereby all of the big cities in the country, it is the very first choice of the city which people are in favor to migrate to. The stability of economy and politics become the main reason for it. But recently Jakarta is now have transformed into big Metropolitan with various people from different ethnics floods its streets. Urban lifestyle is so thick on its atmosphere, on its buildings.

The two observed building becomes the answer on how Jakarta people are evolved, from the "Great Kampung" in the 1960s then become a great Metropolitan that still could support its people. And it evolves rapidly. Perhaps, in the first place, the reason why Jakarta is evolving rapidly is that its status as a national capital.

The capital of a nation is always seen by the world. The capital city is also where the government plays its role to coordinate the country until its most remote area. But all kinds of development in the nation has to be tested by creating the pilot project. On New Order era (1966-1998), the development in Indonesia is always centralized and Jakarta-based. Jakarta is always a pilot project for every government's program. All the success and all the fails have happened here. The success story is what makes Jakarta great. That is why the rise of the middle-high class has first happened here.

Surabaya, on the other hand, it's still gripped on the track to the Metropolitan, unlike Jakarta, which already becomes a Metropolitan. This city saw the development in the 1980s, boosted by infrastructure projects such as new access road and toll road to the west. First grows here are the new housing complex built by the government. Then the roads. The development itself pushes Surabaya to expand the border. The single central hub of the city then divided and moved further south, east, and west. Creating the large new city nodes.

When the economy stabilized, there is also the consequence of the rising middle-high class in the city. People are demanding more for high-class experience in the city, so they made the high-class building such as air-conditioned department store. The status of Surabaya as provincial capital also made people from rural or suburban communities around city try to get some luck here.

But talking the urban changing by the aspect of architecture is somehow has a negative effect on this rising urban society. The simplest thing is the change of airport's architecture. Recent new architecture project of airports are no longer include the local 
and traditional values in their core. Of course, there are some, but since the new construction technique was introduced, ultimately by their ability to push the budget down, the sophisticated technique on detailing has been neglected and people in recent culture perhaps viewed that traditional values are unnecessary.

The most valued thing is the efficiency and its functionality. This design changing perhaps should be allowed only on the building that has the aim for business only, such as malls. The malls or other new commercial buildings in recent years shows the new trend of aluminum cladding usage on many parts of its façade. There is also the usage of large glass as the building envelope, especially for high-rise buildings.

Perhaps that is why the government on the recent projects tends to "imitate" it so they planned the airport with aluminum cladding and glass wall, making the ambience more futuristic and modern. But this is where the things going wrong. The airport is should be a gateway to a place, to a destination. People, especially from abroad, should experience a different thing when entering an airport in this country.

The past governments already did that with Soekarno-Hatta International Airport on the first and second phase. And now, by creating the third phase, they seem to like putting most of the domestic flights on the old terminals. The international passengers then, from their already shiny silver and glass-walled then come to another silver and glass-walled building. And then they offered the tourism promotion from the government. Yet the very first building that greets them just has no difference from where they from. The airport, mainly the international airport, supposed to reflect its Indonesian character, Indonesian arts, Indonesian building techniques that made us really proud of our identity by showing them our finest of everything at the airport. The government must be bear their mind about the middle-high class now: to build a masterpiece that a little bit more expensive but by that sacrifice, it could give us a national pride.

Meanwhile, the growing of department stores in our cities is understandable. There are also some department stores designed for middle-low class so people choose where they like to go and spend their money with. On the future, perhaps the most of settlements are changing into a well-managed settlement, regions will change, more buildings will go up, middle-high class society will rise more, and one by one city in Indonesia will turn into a Cosmopolitan.

\section{REFERENCES}

Andreu, Paul (1995). Landscaping Integration of the Soekarno-Hatta Airport. Unpublished Document. Paris: The Aga Khan.

Barker, Chris (2003). Cultural Studies: Theory and Practice. London: Sage.

Kusno, Abidin (2000). Behind the postcolonial: Architecture, urban space, and political cultures in Indonesia. Psychology Press.

Lubis, Akhyar Yusuf (2014). Postmodernisme, Teori dan Metode. Jakarta: Rajawali Press.

Miller, Toby (2007). Cultural Citizenship: Cosmopolitanism, Consumerism, and Television in a Neoliberal Age. Philadelphia: Temple University Press.

Rundell, John (2001). Modernity, Enlightenment, Revolution and Romanticism: Creating Social Theory. In Ritzer, George, et all (eds), Handbook of Social Theory. London: Sage.

Sukmana, Yoga (2016). Megah dan Modern, Berapa "Airport Tax" T3 Ultimate Bandara SoekarnoHatta?. Kompas. Retrieved on http://ekonomi. kompas.com/read/2016/06/10/062708726/ megah.dan.modern.berapa.airport.tax. t3.ultimate.bandara.soekarno-hatta., access 10 January 2018.

Vickers, Adrian (2005). A History of Modern Indonesia. New York: Cambridge University Press. 